\title{
Adaptative character of a Robertsonian fusion in chromosomes of the fish Gobius paganellus (Pisces, Perciformes)
}

\author{
Angel Amores, \\ Vicente Giles, \\ Guillermo Thode, and \\ $\mathrm{M}^{\mathrm{a}}$ Carmen Alvarez
} Departamento de Genética, Facultad de Ciencias, 29071 Málaga, Spain

Four new karyomorphs have been detected in extending the study of Gobius paganellus' chromosomal polymorphism to a distance of about $1000 \mathrm{~km}$ along the south-east Spanish coast. These new morphs are equivalent to others previously found (Thode et al., 1985), in which a second chromosome fusion (F', by Giles et al., 1985) is present. Frequency distribution of $F^{\prime}$ in the sampled area shows significant differences between both the western and eastern zones, suggesting that this rearrangement has an adaptative character related to the interaction of Mediterranean and Atlantic environmental conditions.

\section{INTRODUCTION}

Chromosome polymorphism in fishes has probably been underestimated mainly because of the small number of individuals usually analyzed from one or more populations, hence failing to observe actual intraspecific variation.

In spite of this, the phenomenon has been especially well documented in salmonids (reviewed by Hartley, 1987), where in most cases, as well as in other fish groups, it is the result of Robertsonian changes. In contrast, very few reports have been concerned with non-Robertsonian polymorphisms, being nevertheless demonstrated by the multiple pericentric inversions observed in mexican populations of the goodeid fish Ilyodon furcidens (Turner et al., 1985).

The relatively high chromosome instability displayed by the teleostean species Gobius paganellus has been manifested in various rearrangements that include: (1) a tandem fusion (Amores et al., 1990); (2) a pericentric inversion (I); (3) two centric fusions ( $\mathrm{F}$ and $\mathrm{F}^{\prime}$ ); and (4) a deletion (D) (Thode et al., 1985; Giles et al., 1985). While the former two have only been detected in one individual, the later three take part in a complex chromosome polymorphism in which two systems can be distinguished on the basis of the chromosome pairs involved.

The first one described (Thode et al., 1985) concerned the same chromosome pair and com- prises six karyomorphs derived from the homozygous and heterozygous combinations of both a deletion (D) and/or a fusion (F). The six karyomorphs are named $\mathrm{B}(2 n=48, \mathrm{NF}=48), \mathrm{D}_{1}(2 n=$ $47, \mathrm{NF}=47), \mathrm{D}_{2}(2 n=46, \mathrm{NF}=46), \mathrm{F}_{1}(2 n=47$, $\mathrm{NF}=48), \mathrm{F}_{2}(2 n=46, \mathrm{NF}=48)$ and $\mathrm{D}_{1} \mathrm{~F}_{1}(2 n=46$, $\mathrm{NF}=47$ ). For practical purposes it will be referred to as the Deletion-Fusion System (DFS).

The latest reported (Giles et al., 1985) was due to another fusion $\left(F^{\prime}\right)$, that involves two different chromosome pairs, and appears together with the DFS, therefore increasing the complexity and interest of this intraspecific chromosome variation. In this paper we attempt to clarify the biological significance of the fusion $F^{\prime}$ on the basis of our present data, after having increased the sample size to an enlarged distance of about $1000 \mathrm{~km}$ along the south-east Spanish coast.

\section{MATERIAL AND METHODS}

A total of 418 immature and adult male and female specimens of G. paganellus were collected from 11 localities along approximately $1000 \mathrm{~km}$ of the south and south-east Spanish coast (fig. 1, table 1).

Sampling was carried out over a four year period (1984-1988) and each locality was sampled one to six times.

Chromosome preparations were obtained by the standard air-drying technique applied to kid- 


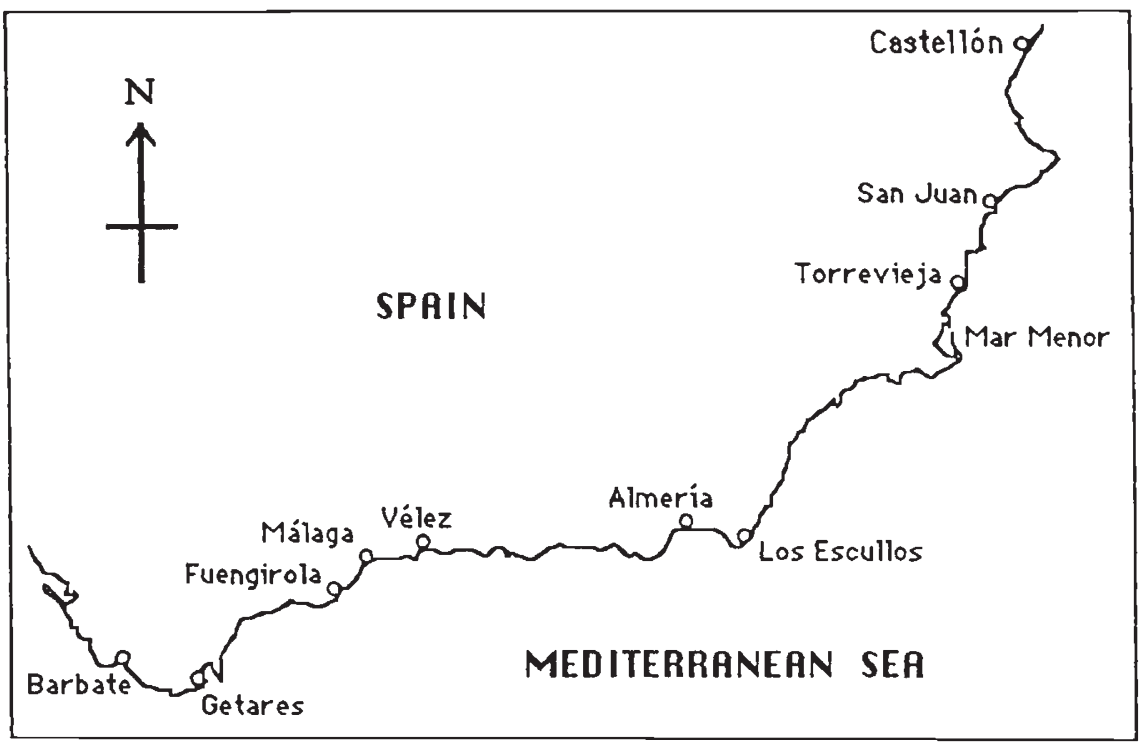

Figure 1 Geographic location of G. paganellus sampling sites.

ney and spleen cells and to gonadal cells when available. Conventional staining was carried out with Giemsa at $p \mathrm{H} 6.8$.

A minimum of 20 well spread mitotic or meiotic metaphases were analysed per individual.

\section{RESULTS AND DISCUSSION}

Four new karyomorphs were observed (fig. 2) that all show the larger biarmed chromosome derived from the previously named fusion $\mathrm{F}^{\prime}$ (Giles et al., 1985). In accordance with the former stated nomenclature for the DFS (Thode et al., 1985), they can be characterized as follows:

$\mathrm{BF}_{1}^{\prime}-(2 n=47, \mathrm{NF}=48)$ consists of one large metacentric and 46 subtelocentric-acrocentrics. This morph represents the basic comp!ement B together with the fusion $F^{\prime}$ in heterozygosity.

$\mathrm{D}_{1} \mathrm{~F}_{1}^{\prime}-(2 n=46, \mathrm{NF}=47)$ shows one large metacentric and 45 mono-armed chromosomes. It would be equivalent to a $D_{1}$ and a $F_{1}^{\prime}$ occurring simultaneously.

Table 1 Individuals analyzed in the different localities (ordered top-down according to a west-east criterium). Left side shows individuals with $\mathrm{F}^{\prime}$ (in brackets) in relation to the DFS morphs. Right side shows total number of analyzed individuals as well as the proportion of those with $\mathrm{F}^{\prime}$

\begin{tabular}{|c|c|c|c|c|c|c|c|c|c|}
\hline \multirow[b]{2}{*}{ Localities } & \multicolumn{6}{|l|}{ DFS } & \multirow{2}{*}{$\begin{array}{l}\text { Total } \\
\text { analysed }\end{array}$} & \multicolumn{2}{|l|}{ Per cent $F^{\prime}$ in } \\
\hline & $\mathrm{D}_{2}$ & $\mathrm{D}_{1}$ & B & $F_{1}$ & $\mathrm{~F}_{2}$ & $\mathrm{D}_{1} \mathrm{~F}_{1}$ & & Heterozygosity & Homozygosity \\
\hline Barbate & $0(0)$ & $0(0)$ & $16(2)$ & $4(0)$ & $0(0)$ & $0(0)$ & 20 & $10 \cdot 00$ & 0.00 \\
\hline Getares $\dagger$ & $0(0)$ & $0(0)$ & $4(0)$ & $14(3)$ & $45(5)$ & $1(0)$ & 64 & $12 \cdot 50$ & 0.00 \\
\hline Fuengirola & $5(1)$ & $1(0)$ & $7(0)$ & $3(0)$ & $9(1)$ & $13(2)$ & 38 & $10 \cdot 52$ & 0.00 \\
\hline Málaga $\uparrow$ & $7(2)$ & $3(0)$ & $2(0)$ & $4(0)$ & $18(2)$ & $20(1)$ & 54 & $9 \cdot 26$ & 0.00 \\
\hline Caleta $\dagger$ & $12(2)$ & $12(1)$ & $6(0)$ & $8(0)$ & $5(0)$ & $18(3)$ & 61 & $11 \cdot 48$ & 0.00 \\
\hline Almerỉa & $12(1)$ & $0(0)$ & $0(0)$ & $0(0)$ & $3(2)$ & $9(4)$ & 24 & $29 \cdot 17$ & 0.00 \\
\hline Escullos $\dagger$ & $11(3)$ & $0(0)$ & $0(0)$ & $0(0)$ & $30(13)$ & $43\left(18^{*}\right)$ & 84 & $39 \cdot 29$ & $1 \cdot 20$ \\
\hline Mar Menor & $7(0)$ & $0(0)$ & $0(0)$ & $0(0)$ & $0(0)$ & $3(3)$ & 10 & $30 \cdot 00$ & 0.00 \\
\hline Torrevieja & $19(5)$ & $0(0)$ & $0(0)$ & $0(0)$ & $1(0)$ & $11(4)$ & 31 & $29 \cdot 03$ & 0.00 \\
\hline San Juan & $21(6)$ & $0(0)$ & $0(0)$ & $0(0)$ & $1(0)$ & $6(4)$ & 28 & $35 \cdot 71$ & 0.00 \\
\hline Castellón & $3(1)$ & $0(0)$ & $0(0)$ & $0(0)$ & $0(0)$ & $1(0)$ & 4 & $25 \cdot 00$ & 0.00 \\
\hline
\end{tabular}

* Including the only individual with $\mathrm{F}^{\prime}$ in homozygosity.

$\dagger$ Most sampled localities. 


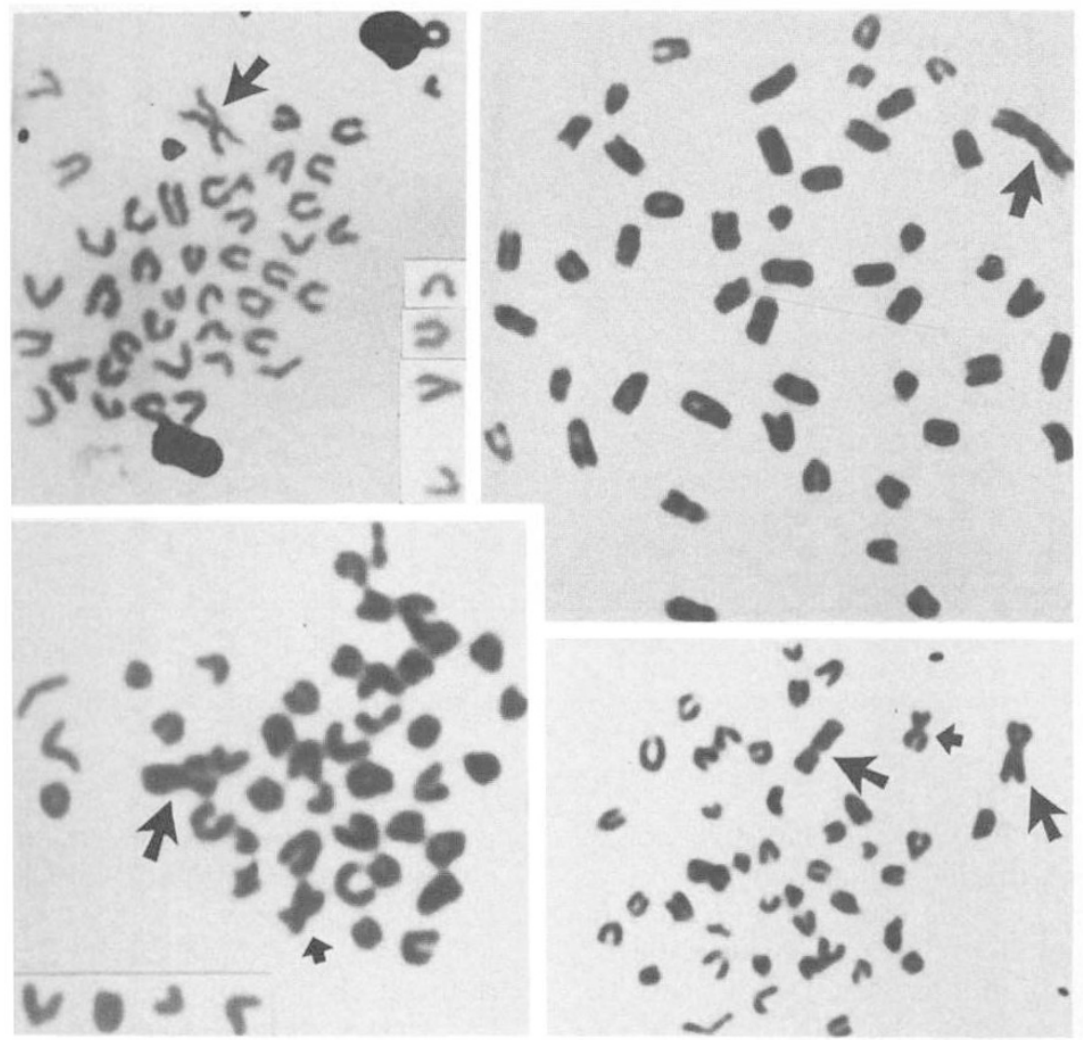

Figure 2 Metaphases of the four new morphs (left to right, top to bottom). $B F_{1}^{\prime}, D_{1} F_{1}^{\prime}, F_{1} F_{1}^{\prime}$, and $D_{1} F_{1} F_{2}^{\prime} . F^{\prime}$ and $F$ chromosomes are respectively indicated by large and small arrows.

$\mathrm{F}_{1} \mathrm{~F}_{1}^{\prime}-(2 n=46, \mathrm{NF}=48)$ displays one median metacentric $(F)$, one larger metacentric $\left(F^{\prime}\right)$ and 44 subtelocentric-acrocentrics. It would be the same case as above but $F_{1}$ instead of $D_{1}$.

$\mathrm{D}_{1} \mathrm{~F}_{1} \mathrm{~F}_{2}^{\prime}-(2 n=44, \quad \mathrm{NF}=47)$ presents one median metacentric (F), two large metacentrics and 42 subtelocentric-acrocentrics. $A_{1} D_{1} F_{1}$ morph with the fusion $\mathrm{F}^{\prime}$ in a homozygous condition.

Detection of the newly described karyomorphs, $\mathrm{D}_{1} \mathrm{~F}_{1}^{\prime}, \mathrm{BF} \mathrm{F}_{1}^{\prime}$ and $\mathrm{F}_{1} \mathrm{~F}_{1}^{\prime}$ (fig. 2) in this larger sample, together with the $D_{2} F_{1}^{\prime}, D_{1} F_{1} F_{1}^{\prime}$ and $F_{2} F_{1}^{\prime}$ reported by Giles et al., (1985), completes the set of karyotypic combinations between the $F^{\prime}$ in single doses and the six karyomorphs of the DFS (Thode et al., $1985)$ in the south Spanish coast populations. It also allows reporting for the first time the homozygous condition for the $F^{\prime}$ in one $D_{1} F_{1} F_{2}^{\prime}$ individual from Escullos (tables 1 and 2).

The spatial distribution of the morphs showing $\mathrm{F}^{\prime}$ is shown in table 1 , where 88 out of 418 individuals posessed the $F^{\prime}$ heterozygous condition in all cells analyzed and only one specimen posessed the $F^{\prime}$ in a homozygous condition $\left(D_{1} F_{1} F_{2}^{\prime}\right)$.

Table 2 Absolute frequencies distribution of $F^{\prime}$ individuals among the six karyomorphs of the DF system. Percentages are indicated in brackets

\begin{tabular}{llll}
\hline & \multicolumn{2}{l}{ Number of individuals } \\
\cline { 2 - 4 } & \multicolumn{3}{c}{ With $\mathrm{F}^{\prime}$ in } \\
\cline { 3 - 4 } Morphs & Without $\mathrm{F}^{\prime}$ & Heterozygosity & Homozygosity \\
\hline $\mathrm{D}_{2}$ & $76(78 \cdot 35)$ & $21(21.65)$ & - \\
$\mathrm{D}_{1}$ & $15(93 \cdot 75)$ & $1(6.25)$ & - \\
$\mathrm{B}$ & $33(94 \cdot 29)$ & $2(5 \cdot 71)$ & - \\
$\mathrm{F}_{1}$ & $30(90 \cdot 91)$ & $3(9 \cdot 09)$ & - \\
$\mathrm{F}_{2}$ & $89(79.46)$ & $23(20 \cdot 54)$ & - \\
$\mathrm{D}_{1} \mathrm{~F}_{1}$ & $86(68 \cdot 8)$ & $38(30 \cdot 4)$ & $1(0.8)$ \\
\hline
\end{tabular}




\section{Relative frequency of $F^{*}$}

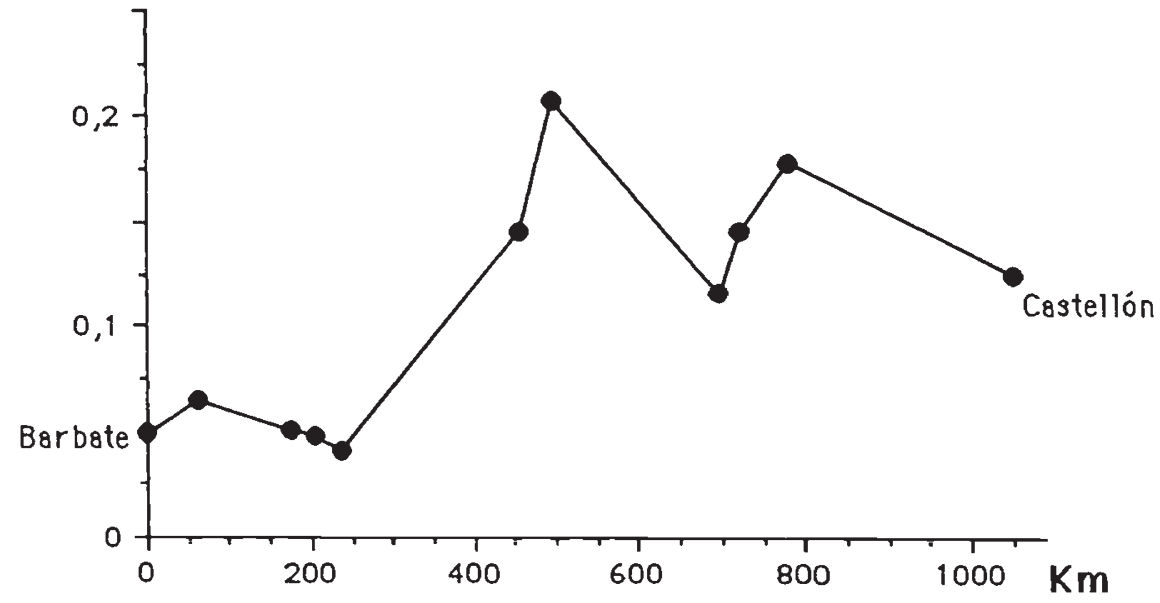

Figure 3 Relative frequencies distribution of the $F^{\prime}$ in the 11 localities along $1000 \mathrm{~km}$ of the south-east Spanish coast.

The presence of $\mathrm{F}^{\prime}$ over a distance of about $1000 \mathrm{~km}$, together with the similarity between our morphs and some of those reported by Vitturi et al., 1984) in the Gulf of Palermo (where the $F^{\prime}$ frequency is roughly similar to that of our eastern localities), clearly suggests that this fusion has a very wide Mediterranean distribution. The marked decreasing of $F^{\prime}$ in our western localities (table 1, fig. 3), might reflect one edge of its distribution.

In our studied area, this decrease in the frequency of $\mathrm{F}^{\prime}$ clearly shows a conspicuous discontinuity between the eastern and western localities (fig. 3). Before analyzing these differences, it became necessary to assess the temporal homogeneity of the samples since, according to Miller (1961), three generations might have overlapped during the four year sampling period at any locality. A chi-square test was applied to the $\mathrm{F}^{\prime}$ frequency from each of the four most sampled localities (table 1, black dots), revealing no significant temporal differences, even in the Escullos station where the highest value was found $\left(\chi^{2}=\right.$ $3 \cdot 484, P=0 \cdot 175, \mathrm{df}=2$ ).

In order to evaluate the above mentioned differences, an independence chi-square test of the $F^{\prime}$ frequencies among all the samples corroborated the existence of significant differences among the localities $\left(\chi^{2}=40 \cdot 948, P \ll 0 \cdot 01, \mathrm{df}=10\right)$. However, separate analyses among the five westernmost stations and among the six easternmost stations revealed a great homogeneity within the two groups $\left(\chi^{2}=0.393, P=0.983, \mathrm{df}=4\right.$; and $\chi^{2}=$ $2 \cdot 223, P=0 \cdot 8175, \mathrm{df}=5$, respectively). This sug- gested a "rupture" between the two areas. Furthermore, this discontinuity coincides with another condition also observed for the DFS (table 1), in which only the three karyomorphs with the most reduced chromosome number $\left(D_{2}, D_{1} F_{1}\right.$ and $\left.F_{2}\right)$ are present in the six eastern localities.

These observations apparently fit with physical (Cano, 1977, 1978) and biological (Rodriguez et al., 1979; Conde and Seoane, 1982) oceanographical data, which establish a certain boundary of Atlantic influence into the Mediterranean Sea, approximately midway between Malaga and Almeria.

In view of all these data, an adaptative interpretation of the $F^{\prime}$ distribution can be suggested in terms of selective processes which apparently may favour karyotypes with reduced chromosome numbers in Mediterranean against Atlantic environmental conditions. This same tendency towards reducing chromosome number has also been shown in the evolution of many fish groups, and similarly has been interpreted as an adaptative trait (Nikolsky, 1976).

Although chromosome polymorphism patterns have generally been interpreted as adaptative strategies (White, 1973; Nevo and Shkolnik, 1974; Turner et al., 1985), only very few investigations have demonstrated the nature of the responsible selective forces (Vest-Pedersen, 1978; Shaw et al., $1985,1987)$. In our case, these seem to be represented by the environmental heterogeneity, due to the Atlantic and/or Mediterranean hydrographic conditions already described. 
A possible association between the two polymorphic systems, DFS and $\mathrm{F}^{\prime}$, was also questioned. Again, we tested the six DFS morphs to the presence/absence of fusion $F^{\prime}$ (table 1) in the western group of localities versus the eastern group. The independence of both variables was shown in the western group $\left(\chi^{2}=4 \cdot 001, P=0.549, \quad \mathrm{df}=5\right)$. Whereas in the eastern group $\left(\chi^{2}=9 \cdot 728, P \ll 0 \cdot 01\right.$, $\mathrm{df}=2$ ) a certain relationship seems to exist. When analysed separately for each eastern locality, Escullos was the only one that did not show such a relationship $\left(\chi^{2}=0.932, P=0.628, \mathrm{df}=2\right)$. These spatial differences again lead us to speculate that an adaptative environmental pattern is involved in the relationship between the two polymorphic systems. In fact, Escullos is a small bay which is perhaps less exposed to open sea conditions than other eastern capture sites (fishing ports, docks, breakwaters).

The interpretation of a general model for the behaviour of the multiple polymorphisms in $G$. paganellus, derived to date from the distribution patterns of the two polymorphic systems, could be useful to establish a certain delineation of biogeographic areas. However, the differences between ecological and cytogenetical studies in this adaptative context will be examined by further investigations using electrophoretic detection of enzymes.

Acknowledgements The authors are specially indebted to G. Dingerkus for critically reading as well as to R. Lawson for the corrections of the manuscript. This research was supported by "Proyecto de Investigación No 3287-83" from the C.A.I.C.Y.T.

\section{REFERENCES}

AMORES, A., GILES, V., THODE, G. AND AlVAREZ, M. C. 1990. A tandem fusion in the fish Gobius paganellus (Gobiidae, Perciformes), a karyotypically polymorphic species. Genome, 33, 57-59.
CANO, N. 1977. Resultados de la campaña “Alborán 73”. Bol. Inst. Esp. Oceanografía, 1, 103-175.

CANO, N. 1978. Resultados de la campaña “Alborán 76". Bol. Inst. Esp. Oceanografia, 4, 3-50.

CONDE, F. AND SEOANE, J. A. 1982. Corología de las especies de algas en relación a ciertos factores ecológicos en el litoral malagueño Collectanea Botanica, 13, 783-802.

GILES, V., THODE, G. AND ALVAREZ, M. C. 1985. A new Robertsonian fusion in the multiple chromosome polymorphism of a Mediterranean population of Gobius paganellus (Gobiidae, Perciformes). Heredity, 55, 255-260.

HARTLEY, S. E. 1987. The chromosomes of salmonid fishes. Biol. Rev., 62, 197-214.

MILLER, P. J. 1961. Age, growth and reproduction of the rock goby, Gobius paganellus (Gobiidae, Perciforms). J. mar. biol. Ass. U.K., 41, 737-769.

NEVO, E. AND SHKOLNIK, A. 1974. Adaptative metabolic variation of chromosome forms in mole rats Spalax. Experientia, 30, 724-726.

NIKOLSKY, G. 1976. The interrelation between variability of characters, effectiveness of energy utilization and karyotype structure in fishes. Evolution, 30, 180-185.

RODRÍGUEZ, J., GARCíA, A. AND RODRÍGueZ, v. 1979. Zooplanktonic communities of the divergence zone in the northwestern Alboran sea. Marine Ecology, 3, 133-142.

SHAW, D. D., COATES, D. J. AND ARNOLD, M. L. 1987. Complex patterns of chromosomal variation along a latitudinal cline in the grasshoper Caledia captiva. Genome; 30, 108-117.

SHAW, D. D., COATES, D. J., ARNOLD, M. L. AND WILKINSON, P. 1985. Temporal variation in the chromosomal structure of a hybrid zone and its relationship to karyotype repatterning. Heredity, 55, 293-306.

THODE, G., GILeS, V. AND Alvarez, M. C. 1985. Multiple chromosome polymorphism in Gobius paganellus (Teleostei, Perciformes). Heredity, 54, 3-7.

TURNER, B. J., GRUDZIEN, T. A., ADKISSON, K. P. AND WORRELL, R. A. 1985. Extensive chromosomal divergence within a single river basin in the goodeid fish Ilyodon furcidens. Evolution, 39, 122-134.

VEST-PEDERSEN, B. 1978. Comparisons of the inversion polymorphism in three danish populations of the midge Chironomus plumosus L. (Diptera: Chironomidae). Hereditas, 89, 151-162.

VITTURI, R., CARBONE, P., CATAlano, E. AND MACALUSO, M. 1984. Chromosome polymorphism in Gobius paganellus Linneo 1758 (Pisces, Gobiidae). Biol Bull., 167, 658-668.

White, M. J. D. 1973. Animal Cytology and Evolution. Third edition, Cambridge Univ. Press. $961 \mathrm{pp}$. 